\title{
MODEL KEMITRAAN PERGURUAN TINGGI-PERUSAHAAN DAN PEMERINTAH DALAM BINGKAI CORPORATE SOCIAL RESPONSIBILITY
}

\author{
Ahmad Kharis, Saipullah Hasan \\ IAIN Salatiga \\ kharisa4@gmail.com,saipulhasan@iainsalatiga.ac.id
}

\begin{abstract}
Abstrak: Dalam konsep pluralisme kesejahteraan (welfare pluralism), usahausaha untuk mewujudkan kesejahteraan sosial dipandang sebagai tanggung jawab bersama, bukan hanya pemerintah saja. Di luar pemerintahan (negara), ada sektor lain yang bertanggung jawab atas kesejahteraan masyarakat yaitu sektor kerelawanan (voluntary), informal, dan komersial. Pandangan ini sedemikian kuat telah mendukung konsep tanggung jawab sosial perusahaan (Corporate Social Responsibility-CSR). Namun, dalam praktiknya upaya mewujudkan CSR tidak berlangsung dengan mudah. Berbagai masalah dapat menjadi kendalanya, misalnya adalah perbedaan pemahaman baik di kalangan internal perusahaan maupun eksternal, adanya ego sektoral dan keterbatasan SDM perusahaan. Dengan demikian, diperlukan kehadiran mediator untuk menyatukan pemahaman serta menyelaraskan kepentingan bersama dalam rangka mewujudkan CSR. Dalam hal ini, perguruan tinggi, termasuk Perguruan Tinggi (PT), sebagai agen pemikiran dan perubahan sosial dapat memegang peranan penting untuk menjalankan fungsi mediasi tersebut melalui suatu model kemitraan. Tulisan ini menganalisis bagaimana model kemitraan antara PT, perusahaan dan pemerintah dalam bingkai CSR yang bermuara pada kesejahteraan masyarakat. Hasil analisis menunjukkan bahwa model kemitraan secara kolaborasi memainkan peran penting dalam menyatukan pemahaman dan menyelaraskan kepentingan bersama guna mewujudkan keberlanjutan bisnis dan kesejahteraan masyarakat.
\end{abstract}

[Abstract: In the concept of welfare pluralism, efforts to realize social welfare are seen as a shared responsibility, not just the government. Outside the government (state), there are other sectors that are responsible for the welfare of society, namely the voluntary, informal and commercial sectors. This view has strongly supported the concept of corporate social responsibility. However, in practice the effort to realize CSR does not take place easily. Various problems can become obstacles, for example differences in understanding both within the internal and external circles, the existence of sectoral egos and the limitations of the company's human resources. Thus, the presence of mediators is needed to unify understanding and align common interests in order to realize CSR. In this case, universities, including tertiary institutions, as agents of thought and social change can play an important role in carrying out the mediation function through a partnership model. This paper analyzes how the partnership between companies, companies and the government in the CSR frame which leads to community welfare. The results of the analysis show that the collaborative partnership model plays an important role in uniting understanding and 
aligning common interests in order to realize business sustainability and public welfare.]

Kata kunci: Model Kemitraan, PT, Perusahaan dan Pemerintah, CSR.

\section{A. Pendahuluan}

Usaha-usaha untuk mewujudkan kesejahteraan masyarakat sejak paruh akhir abad ke-20 dipandang bukan lagi sekadar tanggung jawab sektor pemerintahan (negara) saja. Tanggung jawab penyejahteraan sosial melibatkan banyak sektor. Neil Gilbert (dalam Midgley, 2009: 236) menyebutkan empat sektor yang terlibat dalam mewujudkan kesejahteraan sosial, yaitu sektor pemerintahan, kerelawanan (voluntary), informal, dan komersial. Sementara itu, Spicker menyebutkan lima sektor yang terdiri dari sektor publik, sektor swasta (private), kerelawanan (voluntary), kerja sama (mutual aid), dan sektor informal (Krisdyatmiko, 2012: 127). Pandangan tentang kesejahteraan masyarakat seperti itu disebut sebagai pluralisme kesejahteraan (welfare pluralism).

Pluralisme kesejahteraan ini sedemikian kuat telah mendukung kehadiran konsep tanggung jawab sosial perusahaan (corporate social responsibility-CSR). Kini di Indonesia, apalagi setelah Reformasi yang membukakan peluang bagi masyarakat untuk menjadi subjek pembangunan,,CSR telah menjadi isu penting berkaitan dengan masalah dampak lingkungan dalam pembangunan berkelanjutan (Poerwanto, 2010: 16).

Dalam level global isu CSR sebenarnya telah mulai muncul pada dekade 1950-an. Tepatnya isu tanggung jawab sosial dalam dunia usaha ini pertama kali digunakan oleh Howard R. Bowen di dalam bukunya yang berjudul Social Responsibilities of the Businessman (1953). Menurut Bowen (1953: 6) tanggung jawab sosial pelaku bisnis dalam membuat keputusan, menjalankan kebijakan dan melakukan tindakan diharapkan dapat menyesuaikan dengan tujuan dan nilai sosial yang dianut masyarakat. Dengan menjalankan bisnis sesuai tujuan dan nilai sosial, suatu perusahaan akan mudah menyesuaikan dengan lingkungan sekitarnya sehingga mudah pula diterima oleh masyarakat.

Di Indonesia kewajiban perusahaan melaksanakan CSR telah diatur dalam Undang-undang No 40 tahun 2007, yaitu undang-undang tentang perseroan terbatas. Dalam undang-undang ini diatur mengenai tanggung jawab sosial dan lingkungan guna mewujudkan pembangunan sosial ekonomi berkelanjutann. Pada Bab V pasal 74 ayat 1-4 dijelaskan mengenai definisi dan sanksi apabila 
perusahaan tidak melaksanakan tanggung jawab sosial dan lingkungan. Menurut Scots (dalam Muthuri dan Gilbert, 2010: 4) tekanan regulasi akan menumbuhkan lingkungan yang kondusif untuk penerapan CSR baik dalam hal fokus sasaran maupun bentuknya. Hal senada juga disampaikan Robert Reich bahwa hukum adalah satu-satunya alat yang memungkinkan untuk mendorong perusahaan agar menjalankan tanggung jawab sosialnya (Shaw, 2009: 570).

Adanya dorongan, tuntutan, kewajiban dan kebutuhan untuk menjalankan tanggung jawab sosial perusahaan tersebut sering kali tidak dapat berlangsung dengan mudah. Persoalan yang biasanya muncul ialah belum adanya kesamaan pemahaman, visi dan misi dalam menentukan keberpihakan di antara para pemangku kepentingan, khususnya perusahaan dan pemerintah. Selain itu, masih juga ada suatu ketidaktahuan dengan siapa seharusnya perusahaan merumuskan dan melaksanakan CSR. Apakah kewenangan mengelola CSR ada di pihak perusahaan ataukah pemerintah yang memiliki otoritas menjalankan amanah undang-undang untuk mengatur daerah dan masyarakatnya? Menurut Susetiawan (2012: 05) setiap pemangku kepentingan, baik pemerintah, perusahaan dan masyarakat masih memiliki pemaknaan sendiri-sendiri tentang CSR.

Munculnya kasus Rancangan Peraturan Daerah (Raperda) Kabupaten Cirebon tentang tanggung jawab sosial merupakan salah satu contoh yang relevan dalam hal ini. Terkait Raperda tersebut, terutama pasal 6 yang menyebutkan bahwa pemerintah daerah berhak menentukan program yang menjadi prioritas perusahaan dalam melaksanakan tanggung jawab sosial dan lingkungan (TJSL), Pusat Studi Pedesaan dan Kawasan (PSPK UGM) menyatakan bahwa peraturan tersebut rentan dimanipulasi oleh elit politik sehingga peraturan tersebut lebih berpihak pada kepentingan mereka dari pada kepentingan yang lebih luas, yakni kepentingan pembangunan masyarakat (Susetiawan, 2012).

Perbedaan pemahaman tentang CSR juga ditemukan dari sudut pandang pemangku kepentingan. Secara lebih spesifik, perbedaan tersebut tentang siapa yang harus bertanggung jawab dalam upaya pemecahan masalah sosial, apakah kewajiban pemerintah atau perusahaan? Munculnya perbedaan penafsiran tanggung jawab sosial tentang kesejahteraan dan pemecahan masalah sosial antara perusahaan dan pemerintah ini dijelaskan oleh Friedman (Henningfeld dkk, 2006: 12). la menyatakan bahwa munculnya isu atau masalah sosial adalah sepenuhnya tanggung jawab negara. Alasannya ialah bahwa perusahaan 
merupakan organisasi bisnis yang tidak terlatih untuk menetapkan dan mencapai tujuan sosial. Jadi, perusahaan cukup bertanggung jawab kepada pemerintah dengan membayar pajak, membuka lapangan kerja dan meningkatkan pendapatan daerah. Oleh karenanya, sebuah kesalahan apabila perusahaan masih dibebani dengan urusan pemecahan masalah sosial karena hal itu merupakan tanggung jawab pemerintah.

Penolakan perusahaan untuk ikut bertanggung jawab atas kesejahteraan dan pemecahan masalah sosial dikarenakan oleh keterbatasan SDM perusahaan dan kepentingan ego sektoral mereka. Untuk merespons berbagai problem tersebut, sudah diperlukan kehadiran mediator guna menyatukan pemahaman dan visi bersama tentang perumusan dan praktik CSR.

Peran mediator dalam hal ini dapat dilakukan oleh perguruan tinggi sebagai lembaga pemikiran dan agen perubahan sosial, termasuk PT yang memiliki karakteristik keagamaan Islam. Karakteristik itu tidak menghalangi PT untuk bersinergi dengan komponen lain untuk mencari model kemitraan antara perusahaan dan pemerintah guna mewujudkan CSR. Sebaliknya, karakteristik itu justru dapat dijadikan sebagai nilai tambah PT dalam usaha mewujudkan CSR. Faktor keislaman dalam hal ini justru dapat meneguhkan CSR dengan memberikan landasan religius terhadap keberadaan CSR ini.

Tidak diragukan lagi bahwa pada dasarnya ajaran dan nilai-nilai keislaman memberikan tekanan yang kuat pada pentingnya manusia mempunyai tanggung jawab dan kepedulian sosial. PT memiliki wilayah kajian keislaman yang strategis untuk mewujudkan tanggung jawab sosial yang akan menguatkan pemberdayaan masyarakat sehingga mereka meraih kesejahteraan. Penelitian ini akan memberikan gambaran utuh tentang model kemitraan antara PT, pemerintah dan perusahaan dalam mewujudkan tujuan pemberdayaan masyarakat.

\section{B. Pembahasan}

\section{Semangat PT Dalam Praktik Tanggung Jawab Sosial}

Dilingkup PT sejauh ini telah terjadi pergeseran penting perihal orientasi pendidikan. Pandangan Islam bahwa tujuan pendidikan adalah mengembangkan kelimuan dan membagi nilai pengetahuan saja kini sudah dianggap ketinggalan zaman kalaupun bukan ditolak. Sebagai gantinya, kini muncul orientasi baru pendidikan, yakni bahwa tujuan pendidikan tidaklah semata-mata untuk memberikan ilmu pengetahuan agama dan menyebarluaskannya untuk kepentingan umat, tetapi untuk kebaikan dalam melakukan pemberdayaan 
masyarakat. Dalam perspektif baru seperti itu, upaya mewujudkan tanggung jawab sosial dipandang sebagai sebuah keharusan dan pada hakikatnya menjadi kebutuhan.

Semangat untuk praktik pendidikan dengan orientasi perubahan sosial ini didasari oleh gagasan Antonio Gramsci tentang intelektual organik (organics intellectual). Menurut Gramsci intelektual organik adalah para intelektual yang memiliki keseimbangan antara teori dan praktik. Tugas intelektual organik tidak sekedar memberikan makna atas realitas sosial, melainkan juga bergerak langsung dalam ranah praksis untuk ikut menciptakan sejarah dengan membangun gerakan pemikiran dan kesadaran kritis guna memberi makna masa depan kita sendiri (Fakih, 2011: xxi).

Gagasan ini relevan dengan amanah Undang-undang No 12 Tahun 2012 bahwa proses pendidikan yang diselenggarakan oleh perguruan tinggi tidak hanya mengemban kepercayaan untuk mengembangkan kelimuan, tetapi juga mengembangkan kemampuan dan potensi akademik guna memberdayakan masyarakat. Lembaga perguruan tinggi adalah bagian dari anggota masyarakat untuk mencerdaskan dan memperbaiki kondisi kehidupan mereka. Lembaga pendidikan perguruan tinggi dapat berdiri dan menyelenggarakan proses pendidikan karena mendapatkan dukungan dan kepercayaan dari masyarakat. Oleh karenanya, sudah seharusnya proses pendidikan tidak hanya dilakukan di lingkungan akademik tetapi juga lebih luas lagi, yakni memberikan pendidikan dan menggerakan perubahan perbaikan di masyarakat untuk membebaskan mereka dari kebodohan, keterbelakangan dan ketidakberdayaan.

\section{Etika sebagai Landasan Kemitraan PT-Perusahaan-Pemerintah}

Meskipun konsep CSR terus berjalan dan mengalami perkembangan bukan berarti bahwa konsep tersebut dapat diterima dan dipraktikkan begitu saja. Harapan di antara berbagai pihak yang terlibat dalam CSR untuk dapat bersinergi dan bekerja sama dalam praktiknya tidak selalu dapat diwujudkan. Tidak jarang yang terjadi justru munculnya rasa saling mencurigai, saling mengedepankan ego dan kepentingan masing-masing, sehingga terjadi resistensi di antara berbagai pihak yang seharusnya terlibat dan bersinergi dalam memujudkan CSR. Dengan sendirinya, hal itu tidak akan memberikan konstribusi bagi keberhasilan pelaksanaan CSR dan lebih jauh bagi kesejahteraan sosial masyarakat di lingkungan perusahaan. 
Lalu, bagaimana seharusnya memaknai CSR? Apakah CSR seharusnya dipahami secara etika berdasarkan atas tuntutan dan kepentingan para pemangku kepentingan seperti pemerintah dan perguruan tinggi? Jika tidak demikian, apakah diserahkan pada penafsiran masing-masing pemangku kepentingan atau diarahkan pada tujuan pembangunan masyarakat untuk kemakmuran dan keadilan sosial.

Perusahaan sebagai entitas bisnis sudah seharusnya menyadari bahwa kehadirannya di tengah kehidupan masyarakat tidak dapat terlepas dari dukungan pemerintah dan penerimaan masyarakat setempat. Sedangkan pemerintah berkewajiban untuk mensejahterakan masyarakatnya. Dengan demikian, perusahaan yang berkepentingan untuk mencari keuntungan haruslah membawa kesejahteraan masyarakat setempat dan pemerintah dapat memberikan peraturan yang memberikan keadilan bagi perusahaan dan masyarakat.

Kepentingan bisnis dalam jangka panjang mau tidak mau harus mempertimbangkan investasi sosial jika bisnis itu ingin tetap bertahan dan berkembang. Pelaku usaha harus melakukan tindakan moral bisnis, menaati aturan pemerintah, peduli pada sesama dan menyeimbangkan serta menyelaraskan pemenuhan kebutuhan bisnis dan sosial. Masing-masing pemangku kepentingan kiranya perlu belajar dan menyadari untuk selalu berpijak pada landasan etis tersebut.

Lebih dalam lagi, etika dapat dijelaskan sebagai nilai-nilai atau norma-norma yang dijunjung oleh seseorang atau sekelompok orang sebagai pedoman dalam bertingkah laku. Dengan demikian, etika ini berlaku baik untuk individu maupun kelompok (Hasan dan Andriyani, 7: 2015). Yang sesuai dengan etika adalah baik secara moral, sedangkan yang tidak sesuai dengan etika adalah buruk secara moral. Jika dikatakan bahwa suatu perbuatan itu kurang etis, artinya ialah bahwa perbuatan tersebut menyimpang dari nilai-nilai dan norma-norma moral yang diterima dalam masyarakat (Bdk. Bertens, 2003: 69). Jika dikaitkan dengan bisnis atau usaha komersial, etika bisnis dapat dipahamkan sebagai sikap moral untuk tidak menekankan bisnis pada upaya memaksimalisasi laba semata-mata, melainkan pada upaya meletakkan segala keputusan dan praktik bisnis di atas dasar kesadaran dan moral.

Sebagai sebuah ilmu atau studi, Henningfield dkk (2006, 23) menyatakan bahwa etika bisnis dapat didefinisikan sebagai studi tentang situasi bisnis, kegiatan dan keputusan dalam menghadapi masalah benar dan salah. Evan dan 
Freeman (Henningfield, 2006: 23) menjelaskan bahwa konsep dasar etika ini berpijak pada pengertian tindakan bermoral sebagai suatu perintah atau imperatif kategoris. Artinya ialah tindakan yang bermoral itu merupakan suatu perintah atau keharusan yang mutlak ditaati, tanpa syarat, tidak tergantung pada berbagai konsekuensi perbuatan (Bagus,1996: 331). Akan tetapi, perintah ini bukanlah paksaan, melainkan sesuatu yang muncul dari pertimbangan dari dalam diri yang meyakinkan dan membuat kita tidak bisa lain kecuali taat dan bertindak menurut nilai-nilai moral.

Jika berpijak pada pengertian tindakan bermoral sebagai suatu imperatif kategoris, maka dalam konteks kemitraan CSR berbagai pemangku kepentingan haruslah memiliki kesadaran sosial, mengutamakan kepentingan sosial atau masyarakat, membela kepentingan masyarakat dan mewujudkan keadilan sosial. Dengan keagamaan Islam sebagai basisnya, PT pada dasarnya memiliki wilayah yang strategis untuk membangun kemitraan sekaligus menanamkan nilai moral dan kesadaran kritis untuk bersama menghadirkan pentingnya kebersamaan untuk berjuang mencapai cita-cita semua orang tentang kesejahteraan dan keadilan sosial.

Perusahaan sebagai entitas bisnis memiliki sumber daya ekonomi yang besar sehingga berpotensi untuk mendayagunakan kekuatan finansial mereka demi kesejahteraan masyarakat. Sedangkan perguruan tinggi menjadi mediator dan fasiliator untuk membantu perusahaan dalam merancang dan membangun sistem kerja sama antara berbagai pemangku kepentingan dalam pelaksanaan CSR guna mencapai keberlanjutan bisnis yang mensejahterakan masyarakat. Di sisi lain, pemerintah memiliki otoritas untuk menegakkan peraturan dan melakukan kontrol dalam usaha mewujudkan CSR hingga mendukung terwujudnya kemakmuran masyarakat. Harapan-harapan pemangku kepentingan itu memungkinkan untuk dicapai jika para pemangku kepentingan saling bekerja sama dengan jalan kemitraan antara perguruan tinggi, perusahaan dan pemerintah. Lalu, bagaimana model kemitraan dalam bingkai CSR yang seharusnya dijalankan? Bagaimana langkah-langkan untuk melakukan kemitraan?

\section{Model Kemitraan Perusahaan, Pemerintah dan Perguruan Tinggi}

Dalam menjalin kemitraan idealnya berbagai pemangku kepentingan dapat bekerja sama dan memberikan kontribusi dalam pembangunan. Masing-masing berkontribusi untuk mewujudkan kesejahteraan sesuai kapasitas dan perannya 
dalam masyarakat. Gambaran yang menyeluruh tentang kemitraan antara perguruan tinggi, perusahaan dan pemerintah, dapat dilihat dalam gambar berikut:

\section{Gambar 1. Pola Kemitraan antara Perusahaan, Pemerintah, dan Lembaga Pendidikan untuk Masyarakat Kota/Kabupaten}

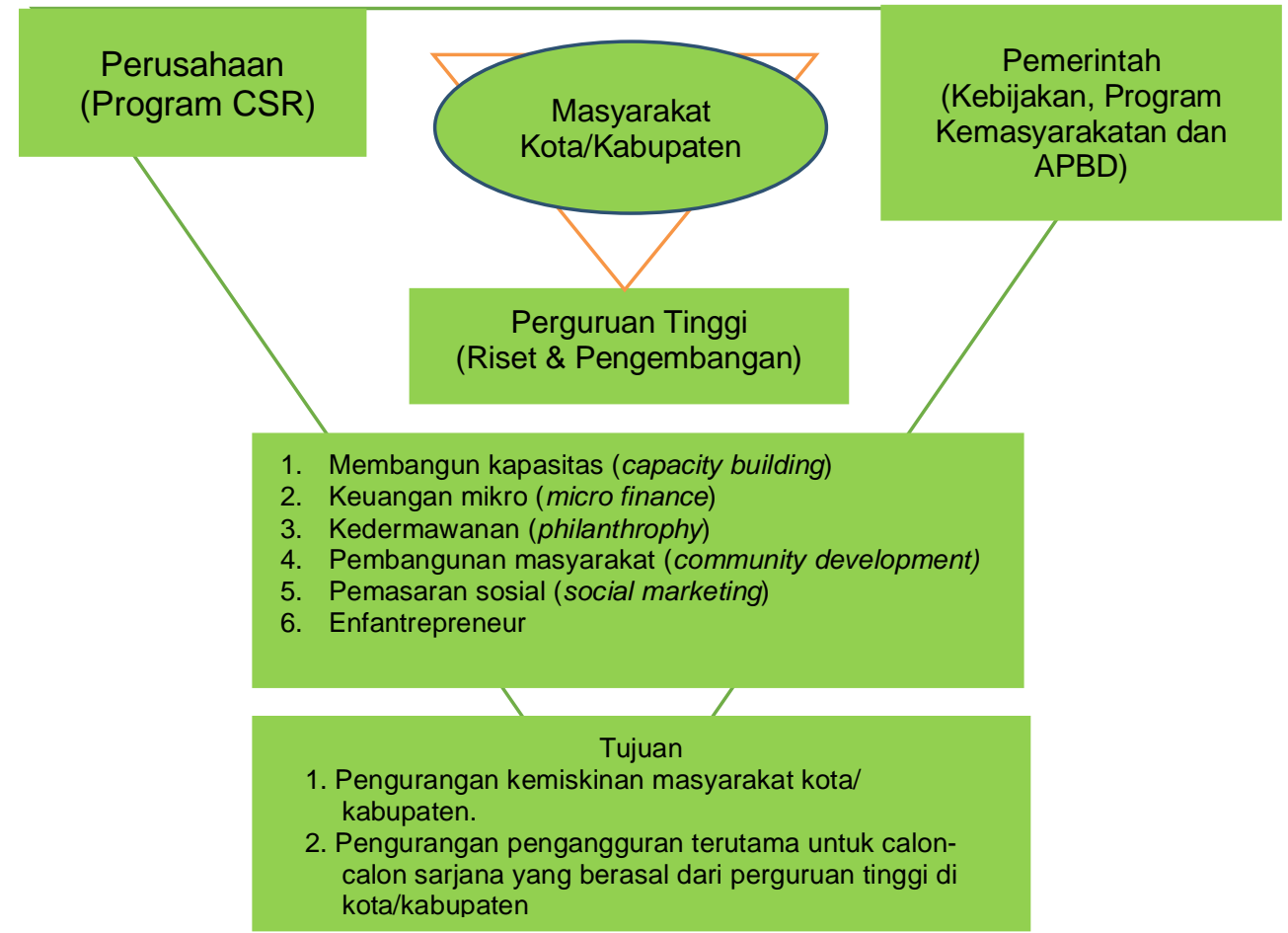

(Sumber: Kartini, 2009, 116)

Dari skema tersebut terlihat masing-masing pihak yang terlibat dalam pola kemitraan mempunyai kompetensi yang saling berkolaborasi. Perusahaan sebagai entitas bisnis memiliki sumber daya keuangan yang besar dapat dimanfaatkan untuk kepentingan masyarakat dalam bentuk program CSR yang tepat sasaran. Kemudian ada pemerintah yang berperan untuk penyediaan kebijakan win-win solution bagi pola kemitraan ini. Selanjutnya, pemerintah juga mempunyai program-program kemasyarakatan yang bisa disinergikan dengan program CSR perusahaan. Selain itu pemerintah memegang kunci dalam mengatur APBD yang berguna untuk pelaksanaan program kerja.

Selanjutnnya, lembaga pendidikan yang dalam hal ini PT jelas memiliki sumber daya manusia dalam bidang riset partisipatoris untuk memberikan rekomendasi dan terlibat langsung dalam aksi program pemberdayaan yang berkelanjutan. Perguruan tinggi memiliki tanggung jawab untuk melaksanakan Tri Darma Perguruan Tinggi yaitu pendidikan, penelitian dan pengabdian masyarakat. 
SDM dari perguruan tinggi yang memiliki keahlian dan pengalaman dapat dijadikan rujukan dalam pembangunan sosial dan kesejahteraan.

Salah satu bidang kerja sama yang dapat dijalankan perguruan tinggi dan perusahaan adalah tentang pemetaan sosial (social mapping) dengan merujuk pada Peraturan Kementerian Lingkungan Hidup No 6 tahun 2013 tentang program penilaian peringkat kinerja perusahaan (Proper) pada Bab IV. Hasil pemetaan sosial dapat dijadikan rujukan utama perusahaan dalam merumuskan program pemberdayaan yang sesuai dengan kebutuhan dan potensi masyarakat.

Dalam konteks hubungan kemitraan antara perusahaan dan perguruan tinggi, perusahaan mengharapkan agar program CSR bisa membantu menyelesaikan permasalahan sosial, seperti masalah pengangguran dan kemiskinan. Terdapat beberapa faktor pendukung dalam melaksanakan program antara perusahaan dengan perguruan tinggi dan pemerintah. Perusahaan memiliki komitmen dalam mengurangi angka kemiskinan dan penggangguran. Perusahaan memandang bahwa kerja sama dengan perguruan tinggi dan pemerintah untuk menggulirkan program CSR mendatangkan kemanfaatan dan keuntungan. Misalnya program menjadi tepat sasaran dan benar-benar berguna bagi penerimanya, terbentuknya citra positif perusahaan karena dinilai peduli oleh masyarakat yang menerima manfaat program CSR tersebut.

Praktik pola kemitraan dapat dilakukan perusahaan dengan perguruan tinggi sebagai mitra. Perusahaan dapat memilih perguruan tinggi yang memiliki program serupa dengan program CSR yang sedang dijalankan, atau program yang sevisi dengan corporate branding yang sedang diusung, ataupun program yang sesuai dengan anggaran yang dimiliki perusahaan. Sebaliknya, perguruan tinggi sebagai pelaksana teknis di lapangan harus mampu menginternalisasikan visi perusahaan dalam setiap tahap yang dilakukan.

\section{Praktik Kemitraan CSR antara perusahaan, perguruan tinggi dan pemerintah dalam Tanggung Jawab Sosial (TJS)}

Kemunculan industri didukung kemajuan teknologi modern secara langsung maupun tidak langsung akan membawa pengaruh terhadap fisik dan non fisik bagi masyarakat sekitar. Perubahan sporadis menunjukkan sinyalemen tumbuhnya kegiatan ekonomi yang subur, namun tidak bisa menolak munculnya pergeseran nilai-nilai kehidupan masyarakat yang tidak diinginkan. Hal ini perlu penyelarasan sosial bagi perusahaan dan masyarakat sekitar amat urgen, dimaksudkan tercipta hubungan 'mutualis' akhirnya menciptakan social 
equilibrium (Tsamara, dkk: 2018). Pola jaringan mutualis bisa diciptakan tanpa mengikis kepentingan bersama, justru akan menguatkan hubungan kolektif dengan mempertimbangkan nilai etis seperti anti-ego sektoral. Menurut Fadilla, dkk (2018) menjelaskan elemen modal sosial yang kuat akan membuat kelompok tersebut juga semakin kompak. Kekompakan kelompok/aktor yang dijaga akan menguatkan solidaritas kelompok, jaringan di dalam kelompok juga terjaga dengan baik sehingga akan semakin mudah mencapai tujuan bersama.

Penelitian ini menjelaskan aktor-aktor yang mengisi pos jaringan kemitraan dalam bingkai Corporate Social Responsibility/CSR. Aktor pola kemitraan dalam penelitian ini melibatkan pihak perusahaan adalah PT. PLN (Persero) Unit Induk Pembangkitan Tanjung Jati B Jepara, pihak pemerintah adalah Pemerintah Daerah Kabupaten Jepara dan pihak perguruan tinggi adalah Departemen Pembangunan Sosial dan Kesejahteraan, Fakultas IImu Sosial dan Politik, Universitas Gadjah Mada.

PT. PLN (Persero) Unit Induk Pembangkitan Tanjung Jati B Jepara merupakan pengelola pembangkit tenaga uap milik negara yang mempunyai kapasitas produksi sebesar 660 X 4 MW Nett berlokasi di Desa Tubanan, Kabupaten Jepara, Jawa Tengah. Pada tahun 2013, 2014 dan 2015, PLN Tanjung Jati $\mathrm{B}$ berhasil memperoleh predikat proper hijau dari Kementerian Lingkungan Hidup. Hal ini memberikan legitimasi sosial bahwa perusahaan dikelola dengan ramah lingkungan serta menjadikan project pilot bagi operasional pembangkit listrik lainnya. Melalui program CSR menciptakan iklim signifikan terhadap proses bisnis yang bebas intervensi warga lokal. Maka perusahaan tidak mengherankan mempunyai label "Beyond Compliance" berkat kinerjanya mengelola lingkungan sekitar, disisi lain perhatian kepada keberlangsungan masyarakat sekitar menjadi kesadaran kolektif dengan kegiatan pemberdayaan.

Universitas Gadjah Mada merupakan kampus ternama mempunyai reputasi nasional dan kancah internasional. Salah satu jurusan yang fokus menyelenggarakan pemberdayaan masyarakat dan CSR adalah Departemen Pembangunan Sosial dan Kesejahteraan. Lebih dari sedekade berkiprah menyelaraskan program CSR perusahaan agar tepat sasaran kepada penerima manfaat. Melalui program CSR perusahaan sebagai langkah realistis mewujudkan kesejahteraan masyarakat, namun sebelum mengawali program pemberdayaan perlu rekomendasi program yang telah disusun dalam Dokumen Pemetaan Sosial. Hal ini akan mempermudah konsep CSR yang berkembang ditengah-tengah 
masyarakat dikenal hanya bagi-bagi, namun lebih dari yang dipersyaratkan perlu dilakukan pada tingkat grassroots sehingga modal dasar manusia (human capital) yang dimiliki daerah tujuan dapat mempunyai kualifikasi yang cukup untuk bekerja sesuai kebutuhan.

Pemerintah Daerah Kabupaten Jepara merupakan lembaga negara yang mempunyai otoritas mengatur, mengelola dan mengawasi seluruh hak dan wewenang termasuk operasional CSR. Maka melalui Pemerintah Daerah Kabupaten Jepara sebagai katalisator program, maka disusun peraturan daerah tentang tanggung jawab sosial perusahaan. Tertuang dalam Peraturan Daerah Nomor 3 Tahun 2014 Tentang Tanggung Jawab Sosial Perusahaan. Demikian ini akan membuktikan komitmen pemerintah daerah meningkatkan kesejahteraan masyarakat secara mandiri, konsisten dan aktif.

Ketiga aktor tersebut mempunyai hubungan mutualis yang digambarkan dalam sebuah gambar dibawah ini:

\section{Gambar 2. Pola Kemitraan Tiga Aktor Dalam Bingkai CSR \\ (Hasil Olahan Data Lapangan)}

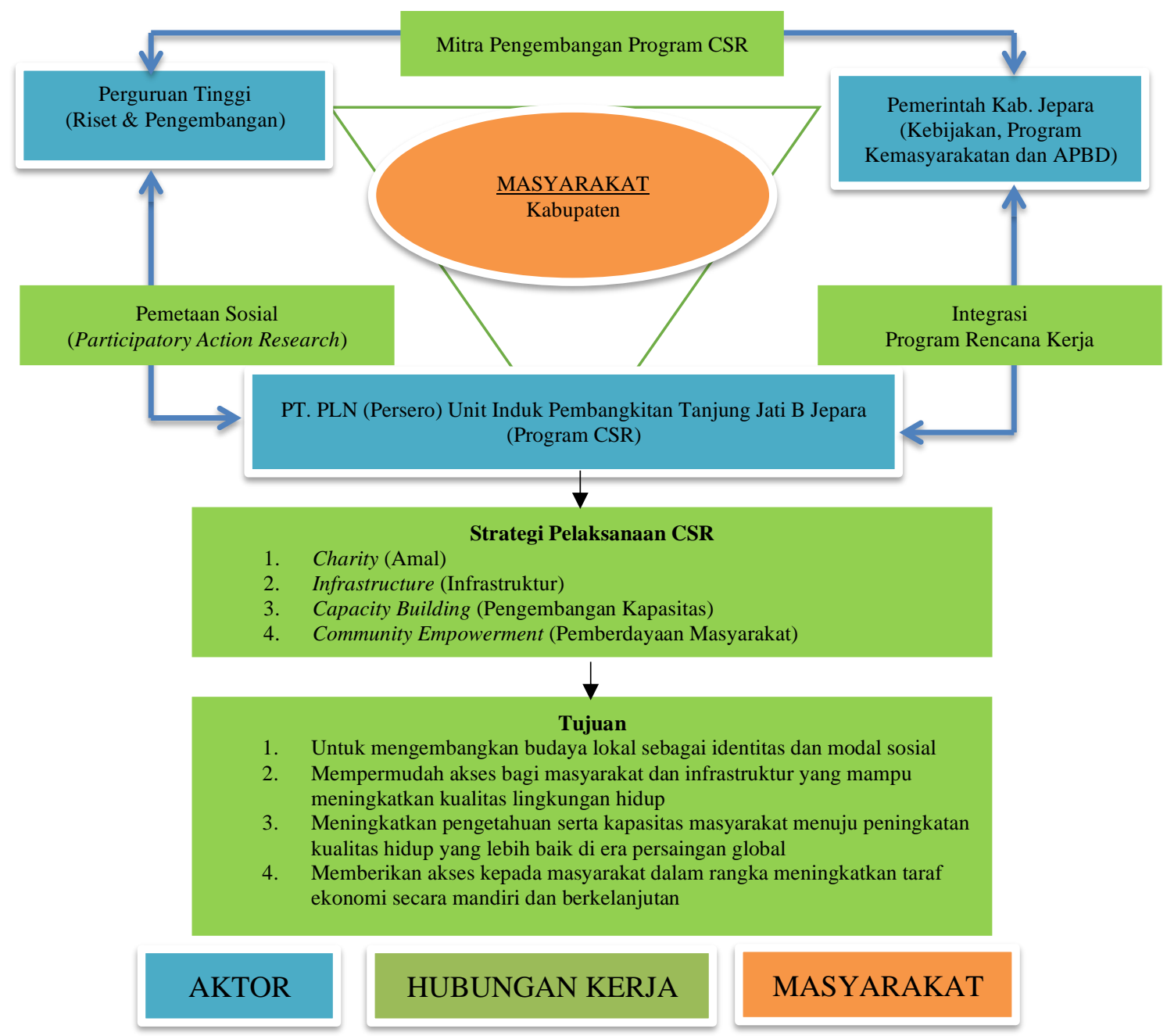

Komunitas Vol. 11, No. 1 (2020) | 49 
Menurut tabel diatas, setiap aktor mempunyai tugas dan fungsi yang saling keterkaitan satu sama lain. Masyarakat menjadi objek vital pemberdayaan didukung sinergitas antar lembaga pendidikan, lembaga daerah dan lembaga korporasi. Lembaga pendidikan yang menjadi representasi adalah Departemen Pembangunan Sosial dan Kesejahteraan (PSdK) Universitas Gadjah Mada Yogyakarta.

Penyelenggaraan program pemberdayaan masyarakat melibatkan multi sektoral yang berkepentingan dan komitmen tinggi adalah perusahaan, perguruan tinggi dan pemerintah daerah. PT. PLN (Persero) UIK TJB sebagai pihak perusahaan melibatkan Pemda Kabupaten Jepara dengan cara mengundang mereka dalam acara kegiatan pelatihan, seminar, perayaan Hari Listrik Nasional hingga seremonial tamu kenegaraan. Salah satu kegiatan melibatkan perusahaan dengan Pemda Kabupaten Jepara konteks pengembangan program CSR adalah komitmen kerjasama produk turunan Program Dotuman Angon.

Adapun produk yang telah dihasilkan antara lain pupuk padat organik, pupuk cair organik dan biogas. Produk tersebut diproduksi oleh kelompok ternak binaan perusahaan melalui Program CSR. Produk label organik perlu dukungan Pemerintah Daerah Jepara sebagai upaya promosi kepada masyarakat, namun sejauh ini belum punya MoU/Memorandum of Understanding antara pihak perusahaan dan pemerintah daerah. Padahal posisi strategis dua aktor ini berperan penting sebagai catalyst sectoral.

Berbicara program CSR perusahaan seperti Dotuman Angon yang bergerak dalam bidang pertanian dan peternakan, memiliki garis struktural yang merepresentasikan kerjasama kepada Dinas Ketahanan Pangan dan Pertanian (DKPP) Kabupaten Jepara. Bentuk konkret kerjasama adalah sinkronisasi program rencana kerja bagi DPP dan perusahaan. Hal ini seperti yang disampaikan oleh Wahyu Mahaputra selaku Asisten Manager CSR saat ditemui di kantor, menjelaskan:

"Program CSR harus menjadi tumpuan primer peningkatan kesejahteraan masyarakat sekitar, terutama masyarakat desa ring 1 perusahaan. Tentu mewujudkan mimpi yang besar tidak bisa khayal berjalan sendiri. Justru kita tetap terus bersinergi antar sektor sesuai kapasitas lembaga yang bersangkutan. Misalnya 
program pemberdayaan Dotuman Angon yang didominasi para petani dan peternak karena tupoksi program mengembangkan ternak kambing. Maka lembaga yang berfungsi sebagai supporting system adalah Pemerintah Daerah atau Dinas. Wujud kerjasama yang menjadi perhatian masyarakat seperti penyelarasan program rencana kerja misalnya program kegiatan pemeriksaan ternak gratis, optimalisasi produk turunan ternak kambing, legalisasi produk hingga edukasi dunia peternakan yang sehat. Jadi program antar instansi kita selaraskan sehingga baik secara efisiensi dan transparansi" (Hasil Wawancara, 18 Januari 2019).

Senada yang telah disampaikan Sumardi sebagai Kepala Seksi Pupuk, Dinas Ketahanan Pangan dan Pertanian (DKPP) Kab. Jepara, menjelaskan:

"Kami bangga melihat semangat para kelompok ternak binaan PLN TJB. Semangat yang pantang menyerah ini berkat hasil kolaborasi rencana kerja Dinas Ketahanan Pangan dan Pertanian dengan Divisi CSR PLN TJB. Kami turut berterima kasih kepada PLN TJB menciptakan kondisi inklusi sosial melalui kelompok ternak binaan. Adapun hasil yang bisa dinikmati adalah hadirnya produk turunan ternak kambing seperti pupuk organik padat, pupuk organik cair dan biogas. Jangka lama melalui produk tersebut akan menciptakan Kabupaten Jepara sebagai kawasan organik lingkup pantura." (Hasil Wawancara, 29 November 2018).

Berikut ini hasil wawancara peneliti dengan Ketua Kelompok Ternak "Mantra 1" tentang kerjasama DKPP dan CSR PLN TJB, menjelaskan:

"Selama kelompok kami dibina oleh CSR PLN selalu disambut positif oleh anggota kelompok ternak lainnya. Antusias mereka terlihat ketika setiap tiga bulan sekali ada acara kunjungan DKPP ke kandang komunal kami. Tentunya pihak dinas memberikan pembinaan kepada kami sebagai peternak desa yang awam terhadap pencegahan dan pengelolaan penyakit ternak. Diantara penyakit ternak yang pernah kami keluhkan adalah majer (mandul) dan demam pada ternak. Pemerintah dalam hal ini 
DKPP turut memberikan vaksin yang disuntikan ke hewan, agar tubuh memiliki daya imun yang kuat melawan berbagai penyakit." (Hasil Wawancara, 5 Febuari 2019).

Berdasarkan wawancara diatas dapat disimpulkan bahwa sinergitas program CSR antara PT. PLN (Persero) UIK Tanjung Jati B Jepara dengan Pemerintah Daerah Kab. Jepara sangat penting. Hal ini dikarenakan kedua aktor mempunyai peran yang berbeda namun tujuan sama adalah meningkatkan kesejahteraan masyarakat. Strategi sinkronisasi program kerja antar lembaga menjadi pilihan otoritatif meskipun terdapat kelebihan dan kelemahan. Kelebihan yang bisa diamati dari kerjasama pola kemitraan tersebut adalah terwujudkan program kerja yang terintegrasi antar aktor pruralisme kesejahteraan. Sedangkan kekurangan adalah timbul fragmen dominasi antar sektor terkait kepentingan anggaran, kebijakan bahkan pelayan kesejahteraan.

Untuk mendukung mekanisme program CSR secara yuridis, melalui Peraturan Daerah Nomor 3 Tahun 2014 Tentang Tanggung Jawab Sosial Perusahaan yang ditandatangani oleh Bupati Jepara. Adapun Undang-Undang ini terdiri dari 17 bab dan total sebanyak 32 pasal. Lebih spesifik tentang kegiatan pemberdayaan masyarakat menurut pasal 11 ayat 1 menjelaskan program tanggung jawab sosial perusahaan di daerah meliputi pemberdayaan masyarakat, kemitraan usaha mikro kecil dan koperasi dan program langsung kepada masyarakat. Ayat 2 menjelaskan program dimaksud ayat (1) sebagai bentuk kontribusi dan kepedulian perusahaan pada bidang sosial, kesehatan, pendidikan, ekonomi dan lingkungan hidup. Oleh karenanya, perlu sinergitas antar sektor dalam hal ini perusahaan dan dinas terkait menyelenggarakan program kegiatan sesuai tujuan negara adalah mensejahterakan kehidupan bangsa (UUD 1945 Alenia 4).

\section{Pilar Kemitraan CSR antara Perusahaan, Pemerintah dan Perguruan Tinggi}

Pandangan lain mengenai hasil pola kemitraan pemerintah, perguruan tinggi dan perusahaan dalam bingkai tanggung jawab sosial perusahaan, memiliki lima poin pelaksanaan CSR (Supriatno, Thendri dalam Besse Asniwaty, 2010) antara lain: Building Human, Strengthening Economies, Assessing Social Cohesion, Encouraging Good Governance dan Protecting The Environment.

Pertama, Building Human adalah menyangkut kemampuan perusahaan memiliki sumber daya manusia (SDM) yang andal (internal) dan masyarakat 
(eksternal). Bagian sumber daya manusia internal menjadi tugas dari korporasi pusat. Sedangkan bagian sumber daya manusia eksternal menjadi tugas tiap perusahaan yang biasanya melalui kegiatan pemberdayaan (community empowerment). PLN TJB telah mempraktikkan konsep ini melalui program CSR tertuang dalam program rencana kerja seperti program dotuman angon, program desa wisata bondo dan program rajungan dan karang endemik pantai utara jawa. Program tersebut tercipta dari rekomendasi program dalam dokumen pemetaan sosial yang dilakukan oleh Departemen Pembangunan Sosial dan Kesejahteraan. Serta kiat sinergi Pemerintah Daerah Kab. Jepara berkomitmen mendukung upaya program tanggung jawab sosial perusahaan secara terus-menerus dan berkelanjutan. Sehingga keseluruhan program menarik perhatian masyarakat berpartisipasi mendukung ketersediaan sumber daya manusia eksternal perusahaan.

Kedua, Strengthening Economies adalah menyangkut kegiatan yang telah berjalan untuk memberdayakan ekonomi komunitas/kelompok. Program-program yang telah didesain dengan baik akan memunculkan efek ekonomi berkelanjutan. Misalnya program dotuman angon memiliki dampak ekonomi bagi anggotanya. Kegiatan memanfaatkan kotoran ternak menjadi sumber daya alami seperti pupuk organik padat, pupuk organik cair dan biogas. Komoditas aspek ekonomi tersebut menjadi tolok ukur keberhasilan program tanggung jawab sosial perusahaan. Kuantitas produk yang dihasilkan oleh kelompok didukung strategi pemasaran yang baik akan menimbulkan peningkatan ekonomi serta kesejahteraan anggotanya. Untuk lebih jelas dibawah ini ditampilkan tabel produk program CSR yang sudah berjalan hingga tahun 2020 .

Tabel 1. Produk program CSR PT PLN (Persero) UIK Tanjung Jati B

\begin{tabular}{|l|l|l|l|}
\hline NO. & NAMA PROGRAM & \multicolumn{1}{|c|}{ PRODUK } & \multicolumn{1}{|c|}{$\begin{array}{c}\text { HARGA } \\
\text { (/pcs) }\end{array}$} \\
\hline 1. & Dotuman Angon & $\begin{array}{l}\text { - Pupuk Organik Padat } \\
\text { - Pupuk Organik Cair } \\
\text { - Biogas 3 kg }\end{array}$ & $\begin{array}{l}\text { - Rp. 15.000/10kg } \\
\text { - Rp. 25.000/1liter } \\
\text { - Rp. 15.000/tabung }\end{array}$ \\
\hline 2. & $\begin{array}{l}\text { Desa Wisata } \\
\text { Bondo }\end{array}$ & - T-Shirt Bondo Beach & - Rp. 55.000/buah \\
& - Hiasan Kaca Kerang & - Rp. 60.000/buah \\
\hline 3. & Juara Mik Pantura & - Kerupuk Rajungan & - Rp. 20.000/bungkus \\
& & - Petis Rajungan & - Rp. 25.000/botol \\
\hline
\end{tabular}

Sumber Data: CSR PT. PLN (Persero) UIK Tanjung Jati B Jepara 
Berdasarkan tabel diatas jika mengamati daftar produk program CSR mempunyai harga yang sangat kompetitif terhadap kelayakan jual di pasaran. Peran masing-masing anggota terbilang aktif ketika mengisi forum pertemuan bulanan. Termasuk pemberian nilai harga terhadap produk mereka sebelum dipasarkan ke beberapa gerai terdekat seperti toko pertanian, toko oleh-oleh dan Rumah Kreatif BUMN (RKB) Kab. Jepara. Hal ini memiliki peluang besar bagi anggota kelompok untuk meningkatkan kekuatan ekonomi serta kemandirian sosialnya.

Ketiga, Assessing Social Cohesion adalah perusahaan mampu menjaga keharmonisan dengan masyarakat sekitar agar tak menimbulkan konflik. Program CSR sudah menjadi tuntutan dari strategi bisnis dalam meningkatkan keuntungan dan pertumbuhan perusahaan yang stabil. Salah satu manfaat mengelola bisnis dengan CSR adalah menjalin hubungan tulus tanpa konflik dengan komunitas karena mereka merasakan langsung komitmen perusahaan melalui pelibatan karyawan mereka dalam mengatasi masalah sosial dalam suatu komunitas misalnya melalui community volunteering charity program (Kartini, 2013). Pengamatan peneliti melihat konflik perusahaan terhadap masyarakat sekitar perusahaan nampak rendah, meskipun ketika musim tertentu seperti musim kemarau. Beberapa masyarakat sekitar yang tinggal disekitar perusahaan mengalami dampak operasional perusahaan antara lain suara bising mesin uap, debu batu bara dan kualitas sanitasi yang buruk. Hal ini jika permasalahan tidak segera diselesaikan akan mengakibatkan proses bisnis perusahaan terganggu. Maka komitmen perusahaan dan masyarakat dalam menjalin sinergi semakin lambat sehingga kepercayaan masyarakat terhadap perusahaan akan luntur. Lebih ekstrim akan terjadi pemboikotan oleh konsumen terhadap produk perusahaan, sehingga menimbulkan kerugian yang luar biasa atau pengrusakan infrastruktur bisnis seperti pagar, kantor, gudang oleh massa karena terjadinya kerusuhan sosial (Sulistiyani, 2004).

Keempat, Encouraging Good Governance adalah perusahaan dijalankan dalam tata kelola yang baik. Konsep ini diperkenalkan oleh Cadbury Committee pada tahun 1992. Mendefinisikan tata kelola perusahaan yang baik sebagai suatu sistem berfungsi untuk mengarahkan dan mengendalikan organisasi, merupakan seperangkat peraturan yang merumuskan hubungan antara para pemegang saham, manager, kreditur, pemerintah, karyawan dan pihak yang berkepentingan baik internal maupun eksternal terkait hak dan tanggung jawab (Tjager, 2003). 
Terkait pengaturan pengelolaan CSR di PLN TJB menampilkan terdapat Jabatan Fungsional Asisten Manager Bidang CSR. Secara struktural jabatan tersebut dibawahnya Manager Keuangan, SDM dan Administrasi (KSA) selanjutnya top direction adalah General Manager. Hal ini menunjukkan pengaturan CSR yang baik akan menyebabkan terjadinya peningkatan nilai (value added) dan kinerja (performance) perusahaan yang maksimal (Saputra, 2002).

Kelima, Protecting the environment adalah perusahaan harus menjaga kelestarian lingkungan. Perusahaan pada dasarnya didirikan untuk memperoleh keuntungan sebesar-besarnya dari kegiatan proses bisnis yang dilakukan, disisi lain harus mampu memberi manfaat bagi lingkungan sekitarnya dan bisa dipertanggungjawabkan. Manfaat program CSR dalam Program Dotuman Angon merupakan upaya strategis menciptakan pengurangan gas emisi karbon yang semakin meningkat di bumi. Berdasarkan data yang dirilis World Resource Institue (WRI) di Washington DC, Amerika Serikat. Indonesia menduduki peringkat ke-6 dunia sebagai negara penyumbang emisi karbon. Indonesia memproduksi emisi karbon sebesar 2,05 miliar ton (Arif, 2019). Salah satu riil penyumbang karbon adalah kotoran makhluk hidup seperti ternak. Di Pulau Jawa, sapi potong memberikan emisi Gas Rumah Kaca tertinggi sebesar 11.684,4 $\mathrm{GgCO}_{2}$-e/tahun (Nurhayati dkk, 2015). Jika kondisi seperti ini dibiarkan akan berdampak buruk terhadap keberlangsungan hidup seluruh ekosistem bumi termasuk paling vital adalah eksistensi manusia. Maka dari itu melalui kegiatan penabungan biogas yang bersumber dari kotoran hewan ternak mengubah gas karbon menjadi gas bio. Salah satu manfaat biogas bagi anggota kelompok ternak bisa substitusi gas elpiji, sehingga menekan pengeluaran ekonomi keluarga yang tergantikan oleh biogas yang murah dan ramah lingkungan. Perlu dukungan pemerintah khususunya Pemerintah Daerah Kab. Jepara sebagai decision maker of policy untuk mendukung operasional biogas semakin berkembang. Pembuatan MoU atau Nota Kesepahaman menjadi langkah konkret menata laju perekonomian masyarakat dibarengi pelestarian lingkungan. Serta peran perguruan tinggi dalam mempromosikan kegiatan tersebut lingkup dunia akademisi.

\section{Simpulan}

Kemitraan antara PT, perusahaan dan pemerintah akan berjalan baik apabila dilakukan secara kolaboratif sehingga tidak ada salah satu pihak yang mendominasi. Peran PT dan pemerintah lebih tepat jika ditujukan untuk mengembangkan prakarsa CSR perusahaan. Pendekatan ini membuka ruang 
untuk saling belajar antara perusahaan dan mitra kerjanya dalam mewujudkan pembangunan dan kesejahteraan masyarakat.

Gagasan kemitraan merupakan peluang sekaligus tantangan. Peluangnya adalah perusahaan dapat berkreasi dan berinovasi dengan beragam institusi lain untuk menciptakan program-program pemberdayaan masyarakat. Adapun tantangannya adalah pelaksanaan CSR harus menjadi bagian integral dari aktivitas bisnis perusahaan, sehingga inisiasi CSR muncul dari dalam diri perusahaan itu sendiri, bukan sekadar dorongan eksternal semata.

CSR sebagai komitmen moral bersama antarpemangku kepentingan (perusahaan, pemerintah, PT) akan berlangsung apabila ada sebuah pemahaman yang sama antarpemangku kepentingan untuk berpihak, membela kepentingan masyarakat yang pada akhirnya dapat menjaga keberlanjutan bisnis. Pada tahap ini etika menjadi hal yang mutlak diperlukan dalam memandu berjalannya kemitraan PT, pemerintah dan masyarakat untuk bersama mengedepankan kepentingan umum dan kesejahteraan bersama.

\section{DAFTAR PUSTAKA}

Arif Andi. 2019. Indonesia Negara Penyumbang Gas Emisi CO2 Nomor 6 Terbesar di Dunia https://badungkab.go.id/instansi/dis/hk/bacaartikel/173/IndonesiaNegara-Penyumbang-Gas-Emisi-CO2-Nomor-6-Terbesar-di-Dunia.html diakses pada tanggal 30 Januari 2020.

Asniwaty, Besse. 2010. Evaluasi Pelaksanaan Coorporate Social Responsibility. Politeknik Negeri Samarinda: Jurnal Eksis Vol.6 No.1, Maret 2010: 1267-1266. Diakses melalui www.karyailmiah.polnes.ac.id pada 20 Januari 2020.

Bagus, Lorens. 1996. Kamus Filsafat. Jakarta: Gramedia.

Bowen, Howard R. 1953. Social Responsibilities of the Businessman. New York: Harper \& Brother.

Fakih, Mansour. 2011. Jalan Lain Manifesto Intelektual Organik. Pustaka Pelajar: Yogyakarta.

Hasan, Saipullah. Andriany, Devy. 2014. Pengantar CSR, Sejarah, Pengertian dan Praksis. Yogyakarta: Pustaka Pelajar.

Hennigfeld, Judith, Pohl Manfred, Tolhurst Nick. 2006. The Icca Handbook On Corporate Social Responbility. England, John Wiley \& Sons Ltd.

Kartini, Dwi. 2009. Corporate Social Responsibility Transformasi Konsep Sustainability Management dan Implementasi Di Indonesia. Bandung: PT Refika Aditama.

Kartini, Dwi. 2013. Corporate Social Responsibility Transformasi Konsep Sustainability Management dan Implementasi Di Indonesia. Bandung: PT Refika Aditama. 
Krisdyatmiko. Kemitraan Pemerintah-Swasta-Masyarakat Dalam Bingkai Forum Multi Stakeholders Corporate Social Responbility (MSH-CSR) dalam Susetiawan. 2012. Corporate Social Responsibility Komitmen Untuk Pemberdayaan Masyarakat. Yogyakarta: Azzagrafika.

Midgley, James (ed.). 2009. The Handbook of Social Policy. London: Sage Publication.

Muthuri N. Judy, Gilbert Victoria. 2010. An Institutional Analysis Of Corporate Social Responsibility In Kenya. Journal Of Business Ethic.

Nurhayati IS dan Widiawati Y. 2017. Emisi Gas Rumah Kaca dari Peternakan di Pulau Jawa yang Dihitung dengan Metode Tier-1 IPCC, Bogor: Prosiding Seminar Nasional Teknologi Peternakan dan Veteriner. Diakses melalui DOI:http://dx.doi.org/10.14334/Pros.Semnas.TPV-2017-p.292-300

Poerwanto. 2010. Corporate Social Responsibility, Menjinakkan Gejolak Sosial Di Era Pornografi. Yogyakarta: Pustaka Pelajar.

Hadi, Nor. 2011. Corporate Social Responsibility. Yogyakarta: Graha Ilmu.

Rahmatullah dan Kurniati, Trianita. 2011. Panduan Praktis Pengelolaan CSR (Corporate Social Responsibility). Yogyakarta: Samudra Biru.

Saputra, Imam dan Amin Widjaja. 2002. Membangun Good Corporate Governance (GCG), Jakarta: Havarindo.

Shaw, HW. 2009. Marxism, Business Ethics, and Corporate Social Responsibility. Journal Of Business Ethics, 84:565-578.

Sulistiyani, Ambar. 2004. Kemitraan dan Model-Model Pemberdayaan. Yogyakarta: Gava Media.

Susetiawan. 2012. Corporate Social Responsibility Komitmen Untuk Pemberdayaan Masyarakat. Yogyakarta: Azzagrafika.

Tjager, Nyoman I dkk, 2003. Dalam Dr. St. Mahendra Soni Indriyo, SH., M.Hum. Dalam Tim Editor Joni Emirzon dkk, 2007, Perspektif Hukum Bisnis Indonesia Pada Era Globalisasi Ekonomi, Yogyakarta: Genta Press.

Tsamara, Y.N, Raharjo, S.T, Resnawaty, R, 2018, Strategi Tanggung Jawab Sosial Perusahaan (CSR) PT Pertamina Melalui Program Kemitraan dan Bina Lingkungan dalam Pertamina Sehati, Vol. 8, No.2, Hal. 219-224, Social Work Journal Universitas Padjajaran: Bandung. Diakses melalui DOI: https://doi.org/10.24198/share.v8i2.20083 pada tanggal 21 Januari 2020.

Undang-Undang No 40 tahun 2007 tentang Perseroan Terbatas.

Peraturan Menteri Negara Lingkungan Hidup No 6 tahun 2013 tentang Program Penilaian Peringkat Kinerja Perusahaan Dalam Pengelolaan Lingkungan Hidup. 